\title{
PERILAKU PEJALAN KAKI PADA TRAFFIC LIGHT DI KABUPATEN MAJENE
}

\author{
Nuraeni $\mathbf{N}^{1}$, Farouk Maricar ${ }^{2}$, Nur Adyla $\mathbf{S}^{3}$ \\ Prodi Teknik Sipil, Fakultas Teknik, Universitas Sulawesi Barat, \\ JL.Prof.DR.Baharuddin Lopa. Lutang. Majene.Tlp/Fax(0422)22559 Kode Pos 91413
}

\begin{abstract}
ABSTRAK
Tujuan yang ingin dicapai melalui penelitian ini adalah untuk menganalisis faktor Perilaku Pejalan Kaki pada pelanggaran lalu lintas di Kabupaten Majene dan untuk menganalisis upaya penanggulangan pelanggaran lalu lintas di Kabupatena Majene. Penelitian ini dilaksanakan di Jl. Gatot Subroto Kabupaten Majene dengan fokus pengamatan dan penataan yaitu bahu jalan, Alat yang digunakan dalam penelitian ini adalah Roll meter untuk mengukur data geometrik jalan seperti lebar jalan dan bahu jalan dan seperangkat alat tulis untuk pencatatan volume lalu lintas. Hasil penelitian yang diperoleh dari pemantauandi Jalan Gatot Subroto memiliki lebar jalan 6,5 m, dengan 1 lajur dalam 1 jalur arah barat, 1 lajur dalam 1 jalur arah timur, dan bahu jalan $1 \mathrm{~m}$ serta zebra cross yang sudah tidak jelas.

Kata Kunci: Perilaku, Pejalan Kaki, Traffic Light, Majene
\end{abstract}

\begin{abstract}
The aim to be achieved through this research is to analyze pedestrian behavior factors in traffic violations in Majene Regency and to analyze traffic violations in Majene District. This research was conducted at Jl. Gatot Subroto Majene Regency with a focus of observation and arrangement that is the road shoulder, The tool used in this study is a Roll meter to measure road geometric data such as road width and road shoulder and a set of stationery for recording traffic volume. The results obtained from the monitoring in Jalan Gatot Subroto have a road width of $6.5 \mathrm{~m}$, with 1 lane in 1 lane west, 1 lane in 1 lane east, and the shoulders of $1 \mathrm{~m}$ lane and zebra crossing that are not clear.

Kata Kunci: Behaviour, Pedestrian way, Traffic Light, Majene
\end{abstract}




\section{PENDAHULUAN}

Peningkatan arus lalu lintas kendaraan dan pergerakan orang diatas prasarana transportasi pada suatu kota seperti prasarana jalan raya perkotaan sangat tergantung pada pesatnya pertumbuhan ekonomi suatu daerah atau wilayah kota. Ini dapat dengan mudah difahami karena transportasi sendiri merupakan kebutuhan turunan (derived demand).

Peningkatan jumlah pergerakan ditandai dengan meningkatnya volume lalu lintas kendaraan maupun volume pejalan kaki pada suatu ruas jalan pekotaan. Pada kenyataannya, peningkatan volume lalu lintas ini mendpaat perhatian hanya pada prasarana lalu lintas kendaraan saja seperti seringnya dilakukan pelebaran jalur lalu lintas, perbaikan struktur perkerasan jalan. Sementara kebutuhan prasarana pejalan kaki seperti fasilitas penyebrangan pedestrian, trotoar bagi pejalan kaki sangat minim mendapat perhatian.

Kondisi seperti berkesan bahwa keselamatan pejalan kaki diperkotaan cenderung terabaikan dan kebijakan-kebijakan yang diambil berpihak kepada pemilik kendaraan, utamanya kendaraan pribadi. Oleh karena itu peningkatan volume lalu lintas kendaraan di jalan raya sangat membutuhkan tersedianya fasilitas pejalan kaki berupa fasilitas penyebrangan pada daerahdaerah dimana pedestrian terkonsentrasi seperti di jalan gatot subroto penyediaan fasilitas penyeberangan adalah untuk meminimalkan konflik antara pedestrian dan kendaraan yang melintas diatas jalan raya. Pemilihan fasilitas penyebrangan pejalan kaki/pedestrian sangat dipengaruhi oleh karakteristik pedestrian dan karakteristik lalu lintas kendaraan yang melintas di jalan raya.

\section{TINJAUAN PUSTAKA}

1) Fasilitas pejalan kaki / pedestrian / bahu jalan

Dilihat dari letak bidangnya, fasilitas penyebrangan pejalan kaki dapat dibedakan atas penyerangan sebidang dan penyebrangan tidak sebidang. Penyebrangan sebidang dapat berupa zebra cross dan lampu kedip dan traffic light sedangkan pengertian dari traffic light adalah lampu yang digunakan untuk mengatur kelancaran lalu lintas disuatu persimpangan jalan dengan cara memberi kesempatan pengguna jalan dari masing-masing arah untuk berjalan secara bergantian.

2) Ketentuan-ketantuan perencanaan fasilitas pejalan kaki

Berdasarkan Surat Keputusan Direktorat Jendral Bina Marga tentang tata cara perencanaan fasilitas pejalan kaki di kawasan perkotaan (tahun 1995), fasilitas pejalan kaki adalah semua bangunan yang disediakan untuk pejalan kaki guna memberikan pelayanan kepada pejalan kaki sehingga dapat meningkatkan kelancaran, keamanan dan kenyamanan pejalan kaki. Fasilitas pejalan kaki harus direncanakan berdasarkan ketentuan-ketentuan sebagai berikut ( Tata Cara Perencanaan Fasilitas Pejalan Kaki di Kawasan Perkotaan.

a. Pejalan kaki harus mencapai tujuan dengan jarak sedekat mungkin, aman dari lalu lintas yang lain dan lancar.

b. Terjadinya kontinuitas fasilitas pejalan kaki, yang menghubungkan satu dengan yang lain.

c. Apabila jalur pejalan kaki memotong arus lalu lintas yang lain harus dilakukan pengaturan lalu lintas, baik dengan lampu pengatur ataupun dengan marka penyebrangan, atau tempat penyebrangan yang tidak sebidang. Jalur pejalan kaki memotong jalur lalu lintas berupa penyeberangan (zebra cross), marka jalanan dengan lampu pengatur lalu lintas (pelican cross).

d. Fasilitas pejalan kaki harus dibuat pada ruas-ruas jalan di perkotaan atau pada tempat-tempat dimana volume pejalan kaki memenuhi syarat atau ketentuan untuk pembuatan fasilitas tersebut.

e. Jalur pejalan kaki sebaiknya di tempatkan sedemikian rupa dari jalur lalu lintas yang lainnya, sehingga keamanan pejalan kaki lebih terjamin.

f. Dilengkapi dengan rambu atau pelengkap jalan lainnya, sehingga pejalan kaki leluasa untuk berjalan, terutama bagi pejalan kaki yang tuna daksa.

g. Perencanaan jalur pejalan kaki dapat sejajar, tidak sejajar atau memotong jalur lalu lintas yang ada. 
h. Jalur pejalan kaki harus dibuat sedemikian rupa sehingga apabila hujan permukaannya tidak licin, tidak terjadi genangan air serta disarankan untuk dilengkapi dengan pohon-pohon peneduh.

i. Untuk menjaga keamanan dan keleluasaan pejalan kaki, harus dipasang kerb jalan sehingga fasilitas pejalan kaki lebih tinggi dari permukaan jalan.

\section{HASIL DAN PEMBAHASAN}

\section{A. Kondisi Geometrik}

Jalan Gatot Subroto memiliki lebar jalan 6,5 m, dengan 1 lajur dalam 1 jalur arah barat, 1 lajur dalam 1 jalur arah timur, dan bahu jalan $1 \mathrm{~m}$ serta zebra cross yang sudah tidak jelas. Berikut kondisi hasil survey dijelaskan dalan Tabel 4.1 dan Gambar 4.1

Tabel 1. Kondisi GeometriRuas Jalan Gatot Subroto

\begin{tabular}{|l|l|l|l|l|l|}
\hline \multirow{2}{*}{ Nama Jalan } & \multicolumn{4}{|l|}{ Kondisi Area Studi } \\
\cline { 2 - 6 } & Median & LTOR & Lebar Jalan & Bahu Jalan & $\begin{array}{l}\text { Zebra } \\
\text { Cross }\end{array}$ \\
\hline $\begin{array}{l}\text { Gatot } \\
\text { Subroto }\end{array}$ & Tidak & Tidak & $6,50 \mathrm{~m}$ & $1 \mathrm{~m}$ & $\begin{array}{l}\text { Ada (Tidak } \\
\text { Layak) }\end{array}$ \\
\hline
\end{tabular}

Sumber : Hasil Survey

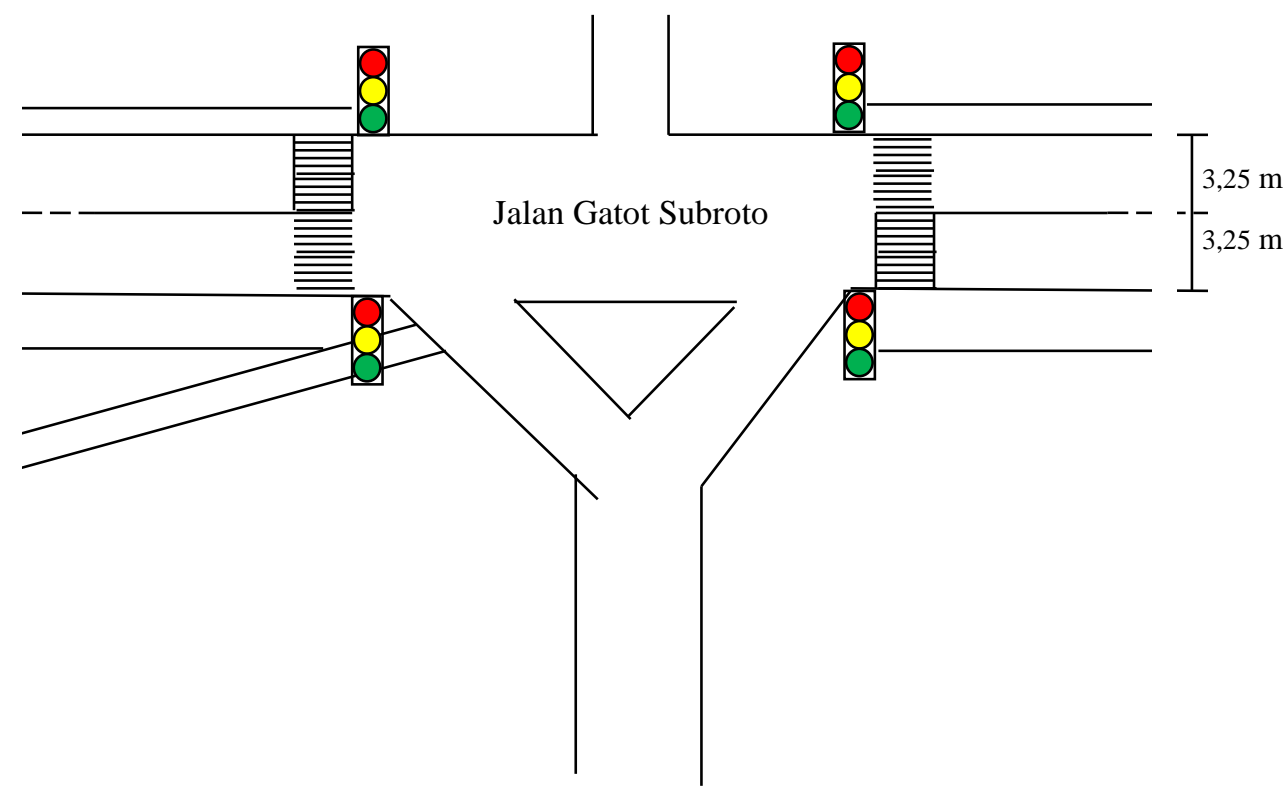

Gambar 1. Kondisi Area Batas Studi Penelitian

\section{B. Data Penyeberang Pejalan Kaki}

Pencacahan volume penyeberang pejalan kaki dilaksanakan bersamaan dengan waktu puncak arus lalu lintas dimana telah diketahui terdapat 3 waktu puncak yaitu puncak pagi, puncak siang dan puncak sore.

\section{Volume Penyeberang Pejalan Kaki Pada Puncak Pagi}

Pada pencacahan volume penyeberang pejalan kaki puncak pagi dibedakan menjadi dua perilaku penyeberang yaitu melalui jembatan dan melalu ruas jalan. Rekapitulasi dikonversi ke dalam satuan waktu per jam. Berikut hasil pencacahan volume penyeberang pejalan kaki disajikan pada Tabel 4.3 dan Gambar 4.3. 
Table 2 Volume Penyeberang Pejalan Kaki Pada Puncak Pagi

\begin{tabular}{|c|c|c|c|}
\hline $\begin{array}{l}\text { Hari / Tanggal } \\
\text { Waktu } \\
\text { Lokasi }\end{array}$ & $\begin{array}{l}\text { Rabu, } 29 \text { November } 20 \\
6.15-08.15 \\
\text { alan Gatot Subroto }\end{array}$ & & \\
\hline \multirow[b]{2}{*}{ Jam } & \multicolumn{3}{|c|}{ Jumlah Penyeberang Pejalan Kaki } \\
\hline & $\begin{array}{c}\text { Melalui } \\
\text { Cross }\end{array}$ & Melalui Ruas Jalan & $\begin{array}{c}\text { Yang Menerobos } \\
\text { Lampu Hijau }\end{array}$ \\
\hline $06.15-07.15$ & 2 & 76 & 20 \\
\hline $06.30-07.30$ & 1 & 125 & 28 \\
\hline $06.45-07.45$ & 0 & 137 & 28 \\
\hline $07.00-08.00$ & 2 & 178 & 33 \\
\hline $07.15-08.15$ & 2 & 162 & 25 \\
\hline
\end{tabular}

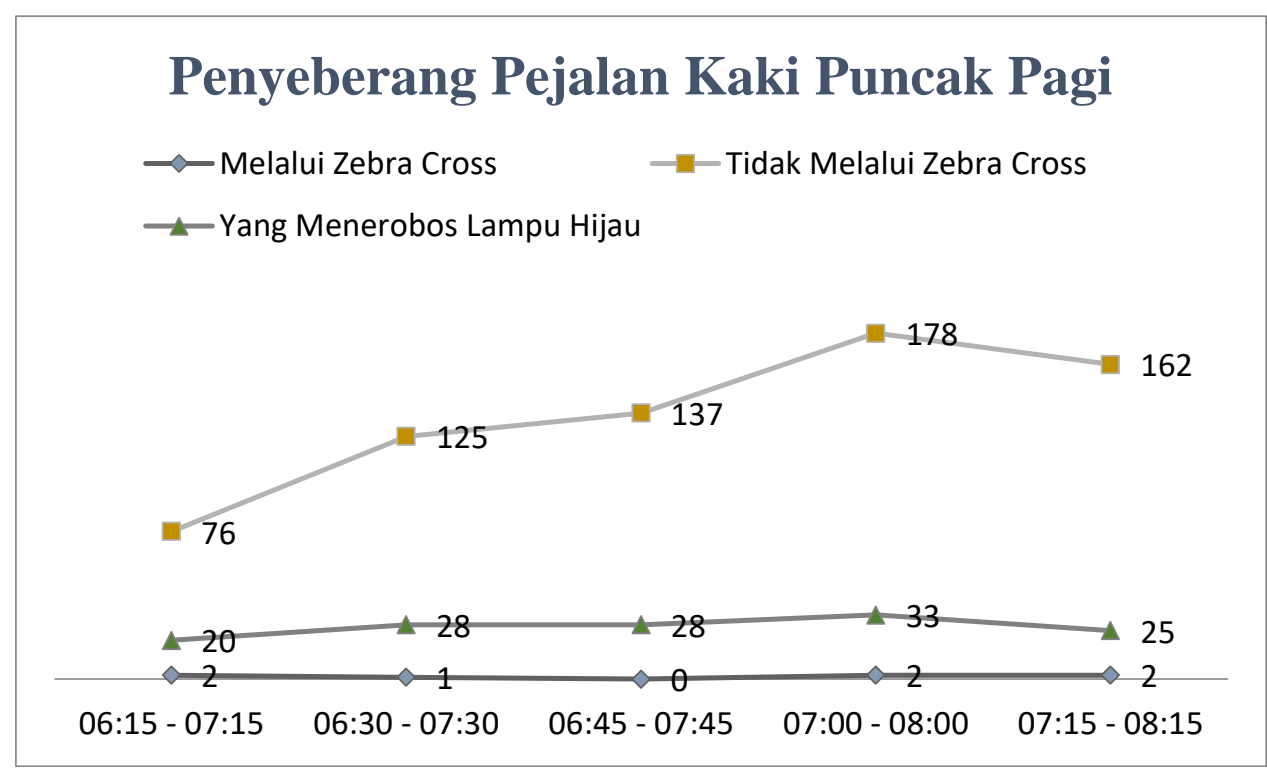

Gambar 4.2 Volume Penyeberang Pejalan Kaki Puncak Pagi

Dari Tabel 2 dan Gambar 2 menunjukkan hasil bahwa pada puncak pagi banyak penyeberang pejalan kaki yang lebih memilih menyeberang dengan menerobos lampu hijau. Puncak penyeberang pejalan kaki dengan menerobos lampu hijau berada pada waktu 07:00 - 08:00 dengan 178 penyeberang sedangkan Puncak penyeberang pejalan kaki tanpa melalui zebra cross berada pada waktu 07:00 - 08:00 dengan 33 penyeberang dan penyeberang pejalan yang melalui zebra cross 06:15 - 07:15, 07:00 - 08:00 dan 07:15 - 08:15 dengan masing-masing 2 penyeberang.

\section{Perilaku Penyebrangan Pejalan Kaki Pada Puncak Pagi}

Dalam pencacahan perilaku pejalan kaki dibedakan menjadi 3 perilaku penyeberang yaitu penyeberangan melalui zebra cross, penyeberangan melalui ruas jalan dan yang menerobos lampu hijau. Rekapitulasi dikonversi ke dalan satuan waktu per 15 menit kemudian di analisa dan dibandingkan persentase jumlah ketiga perilaku tersebut. Berikut hasil pencacahan perilaku penyeberangan pejalan kaki disajikan pada table 3 dan gambar 3. 
Table 3 Perilaku Penyeberangan Pejalan Kaki Pada Puncak Pagi

\begin{tabular}{|c|c|c|c|c|c|}
\hline $\begin{array}{l}\text { Hari / Tanggal } \\
\text { Waktu } \\
\text { Lokasi }\end{array}$ & $\begin{array}{l}\text { : Rabu, } 2 \\
\text { : 06.15- } \\
\text { : Jalan G }\end{array}$ & $\begin{array}{l}9 \text { November } 20 \\
08.15 \\
\text { atot Subroto }\end{array}$ & & & \\
\hline PERILAKU I & PENYEBE & RANG PEJAI & KAKI & & \\
\hline Melalui Zebr: & a Cross & Melalui Ruas & & $\begin{array}{c}\text { Yang Mener } \\
\text { Hijau }\end{array}$ & s Lampu \\
\hline Waktu & Jumlah & Waktu & Jumlah & Waktu & Jumlah \\
\hline $\begin{array}{c}06: 15 \\
06: 30\end{array}$ & 1 & $06: 15-06: 30$ & 25 & $06: 15-06: 30$ & 8 \\
\hline $\begin{array}{c}06: 30 \\
06: 45\end{array}$ & 1 & $06: 30-06: 45$ & 22 & $06: 30-06: 45$ & 4 \\
\hline $\begin{array}{cc}06: 45 & - \\
07: 00 & \\
\end{array}$ & 0 & $06: 45-07: 00$ & 9 & $06: 45-07: 00$ & 3 \\
\hline $\begin{array}{c}07: 00 \\
07: 15\end{array}$ & 0 & $07: 00-07: 15$ & 20 & 07:00 - 07:15 & 5 \\
\hline $\begin{array}{c}07: 15 \\
07: 30\end{array}$ & 0 & $07: 15-07: 30$ & 74 & $07: 15-07: 30$ & 16 \\
\hline $\begin{array}{cc}07: 30 & - \\
07: 45 & \\
\end{array}$ & 0 & $07: 30-07: 45$ & 34 & $07: 30-07: 45$ & 4 \\
\hline $\begin{array}{c}07: 45 \\
08: 00\end{array}$ & 2 & $07: 45-08: 00$ & 41 & $07: 45-08: 00$ & 5 \\
\hline $\begin{array}{cc}08: 00 & - \\
08: 15 & \\
\end{array}$ & 0 & $08: 00-08: 15$ & 13 & 08:00 - 08:15 & 0 \\
\hline Total & 4 & Total & 238 & Total & 45 \\
\hline Volume $=\frac{T}{P}$ & $\begin{array}{l}\text { otal melalui } \\
\text { enyeberang }\end{array}$ & $\begin{array}{l}\text { ebra cross }+\mathrm{T} \\
\text { ang menerobo }\end{array}$ & $\begin{array}{l}\text { ang tidak } \\
\text { u hijau }\end{array}$ & lalui zebra crc & Total \\
\hline
\end{tabular}

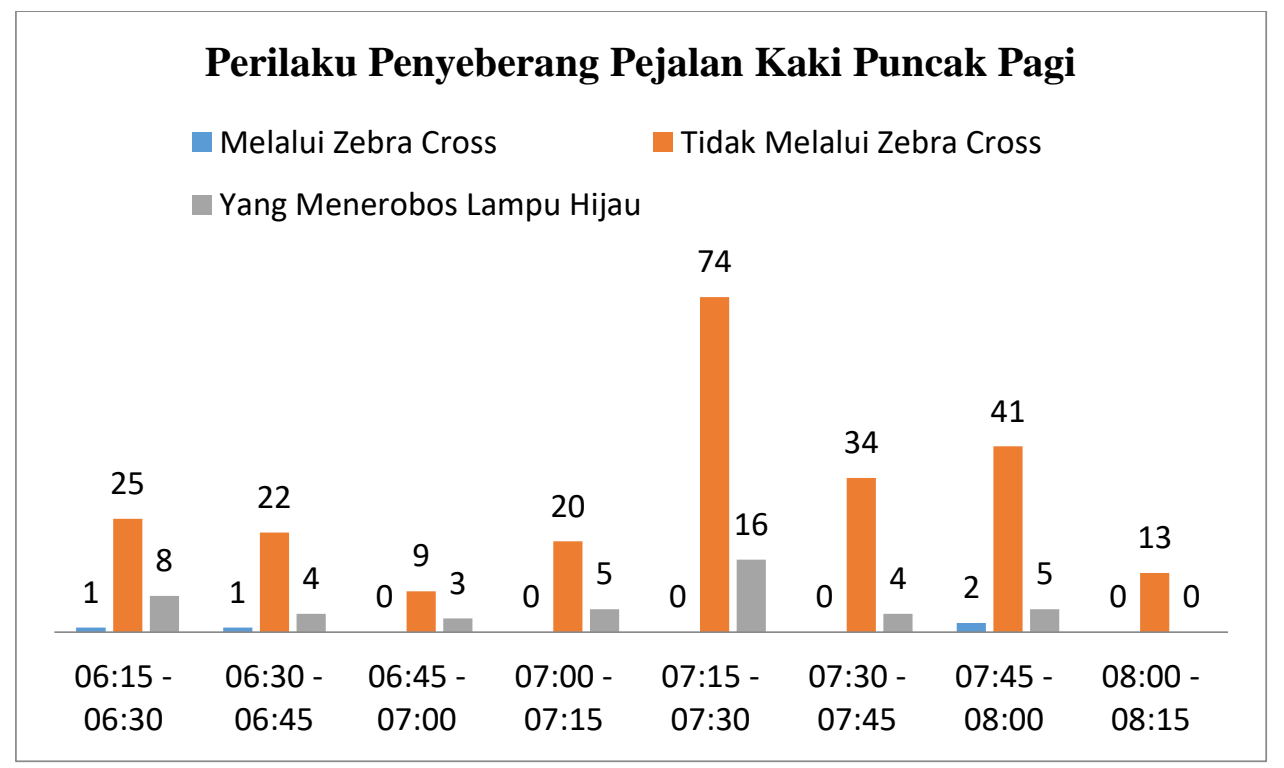

Gambar 3 Perilaku Penyeberang Pejalan Kaki Puncak Pagi 
Dari Tabel 3 dan Gambar 3 menunjukkan bahwa pada puncak pagi terdapat kemudian penyeberang yang tidak melalui zebra cross sebanyak 74 penyeberang, penyeberang yang menerobos lampu hijau sebanyak 16 penyeberang kemudian penyeberang pejalan kaki melalui Zebra Cross sebanyak 2 penyeberang. Hasil tersebut menyimpulkan bahwa penyeberang lebih banyak memilih tidak menggunakan Zebra Cross dari pada menyeberang sesuai trafict light atau melalui Zebra Cross. Dan dapat disimpulkan bahwa zebra cross dan trafict light tidak berfungsi efektif.

\section{Persentase Perilaku Penyeberang Pejalan Kaki Puncak Pagi}

Pada perhitungan persentase perilaku penyeberang pejalan kaki, jumlah penyeberang masingmasing perilaku dibagi total penyeberang kemudian dikalikan bilangan 100 .

Table 4. Volume Penyeberang Pejalan Kaki Pada Puncak Pagi

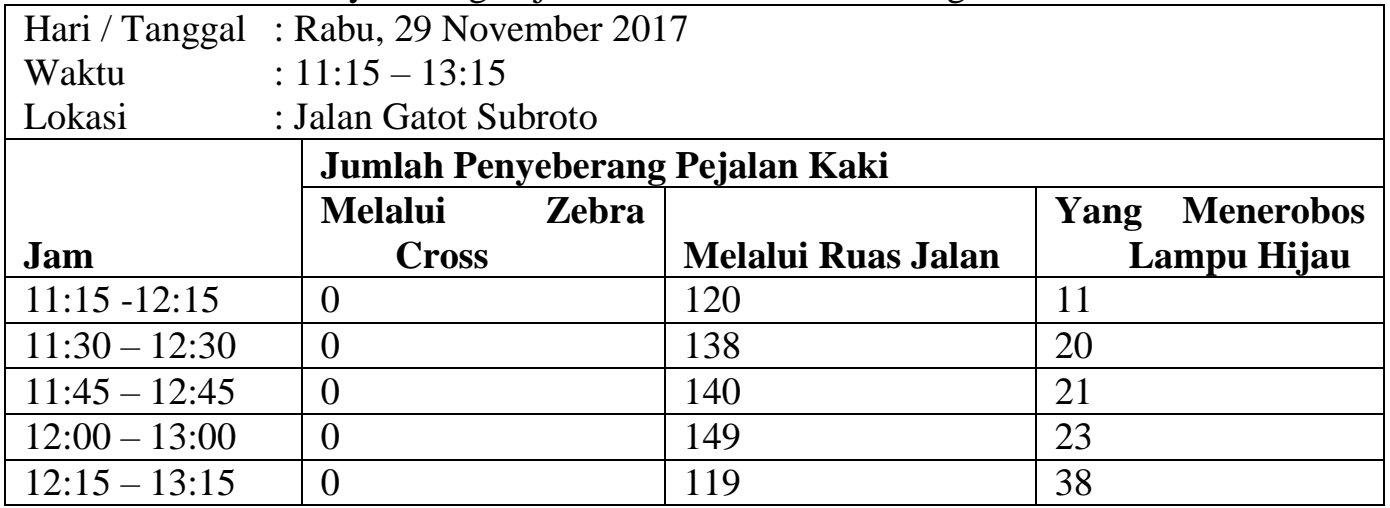

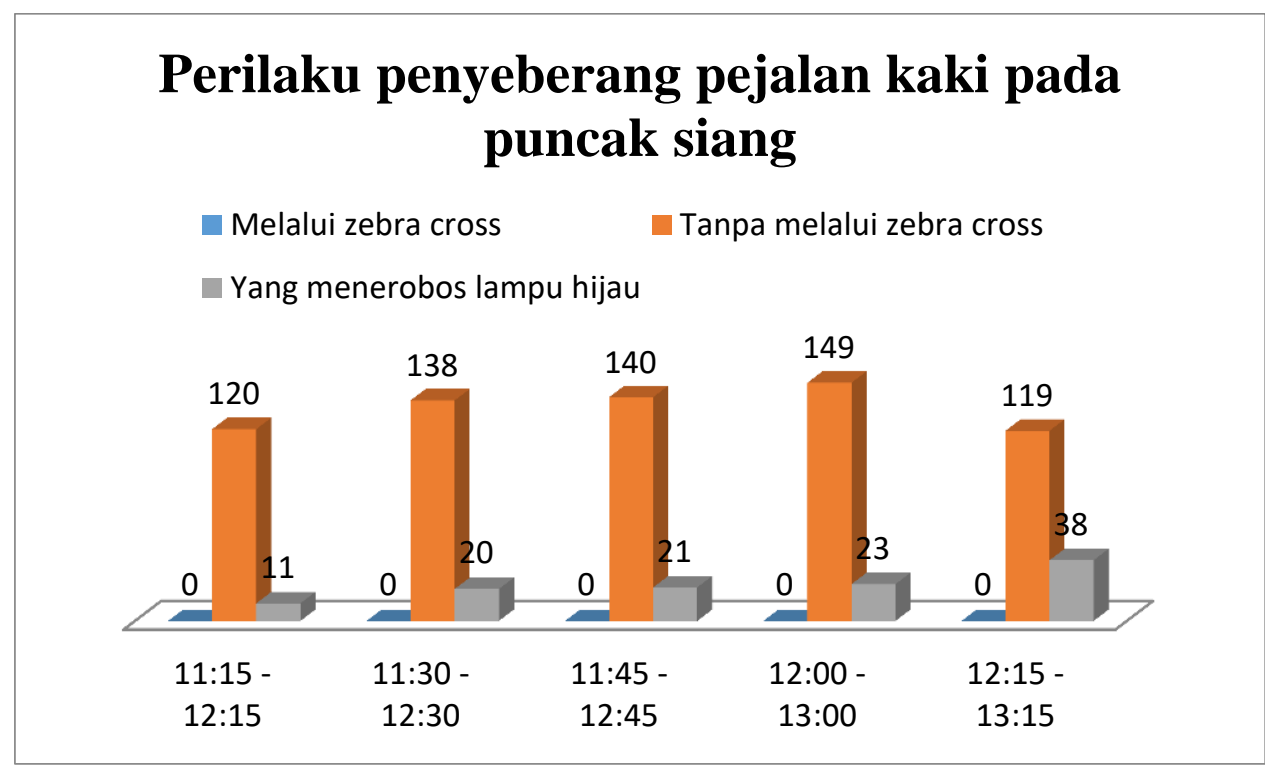

Gambar 4 Volume Penyeberang Pejalan Kaki Puncak Siang

Dari Tabel 4 dan Gambar 4 menunjukkan hasil bahwa pada puncak siang banyak penyeberang pejalan kaki yang lebih memilih menyeberang dengan menerobos lampu hijau. Puncak penyeberang pejalan kaki dengan menerobos lampu hijau berada pada waktu 12:15 - 12:30 dengan 38 penyeberang sedangkan Puncak penyeberang pejalan kaki tanpa melalui zebra cross berada pada waktu 12:00 - 13:00 dengan 149 penyeberang.

\section{Perilaku Penyebrangan Pejalan Kaki Pada Puncak Siang}

Dalam pencacahan perilaku pejalan kaki dibedakan menjadi tiga perilaku penyeberang yaitu penyeberangan melalui zebra cross, penyeberangan melalui ruas jalan dan yang menerobos 
lampu hijau. Rekapitulasi dikonversi ke dalam satuan waktu per 15 menit kemudian di analisa dan dibandingkan persentase jumlah kedua perilaku tersebut. Berikut hasil pencacahan perilaku penyeberangan pejalan kaki disajikan pada table 5 dan gambar 5 .

Table 5 Perilaku Penyeberangan Pejalan Kaki Pada Puncak Siang

\begin{tabular}{|c|c|c|c|c|c|}
\hline $\begin{array}{l}\text { Hari / Tangga } \\
\text { Waktu } \\
\text { Lokasi }\end{array}$ & $\begin{aligned} 1 & : \text { Rabu, } \\
& : 11: 15 \\
& : \text { Jalan }\end{aligned}$ & $\begin{array}{l}9 \text { November } 20 \\
13: 15 \\
\text { atot Subroto }\end{array}$ & & & \\
\hline PERILAKU & PENYEB & RANG PEJAI & KAKI & & \\
\hline Melalui Zebr & a Cross & Melalui Ruas & & $\begin{array}{l}\text { Yang Menerobc } \\
\text { Hijau }\end{array}$ & s Lampu \\
\hline Waktu & Jumlah & Waktu & Jumlah & Waktu & Jumlah \\
\hline $\begin{array}{c}11: 15 \\
11: 30 \\
\end{array}$ & 0 & $11: 15-11: 30$ & 23 & $11: 15-11: 30$ & 3 \\
\hline $\begin{array}{c}11: 30 \\
11: 45\end{array}$ & 0 & $11: 30-11: 45$ & 32 & $11: 30-11: 45$ & 2 \\
\hline $\begin{array}{r}11: 45 \\
12: 00\end{array}$ & 0 & $11: 45-12: 00$ & 29 & $11: 45-12: 00$ & 2 \\
\hline $\begin{array}{c}12: 00 \\
12: 15\end{array}$ & 0 & $12: 00-12: 15$ & 36 & $12: 00-12: 15$ & 4 \\
\hline \begin{tabular}{|c|}
$12: 15$ \\
$12: 30$ \\
\end{tabular} & 0 & $12: 15-12: 30$ & 41 & $12: 15-12: 30$ & 12 \\
\hline $\begin{array}{c}12: 30 \\
12: 45\end{array}$ & 0 & $12: 30-12: 45$ & 34 & $12: 30-12: 45$ & 3 \\
\hline $\begin{array}{c}12: 45 \\
13: 00\end{array}$ & 0 & $12: 45-13: 00$ & 38 & $12: 45-13: 00$ & 4 \\
\hline \begin{tabular}{|cc}
$13: 00$ & - \\
$13: 15$ & \\
\end{tabular} & 0 & $13: 00-13: 15$ & 13 & $13: 00-13: 15$ & 6 \\
\hline Total & 0 & Total & 246 & Total & 36 \\
\hline Volume $=$ & $\begin{array}{l}\text { Total melal } \\
\text { Penyeberan }\end{array}$ & $\begin{array}{l}\text { i zebra cross }+ \\
\text { yang menerob }\end{array}$ & $\begin{array}{l}\text { yang tidal } \\
\text { pu hijau }\end{array}$ & elalui zebra cros & Total \\
\hline $\begin{array}{l}= \\
=\end{array}$ & $\begin{array}{l}0+246+ \\
282 \text { Peny }\end{array}$ & $\begin{array}{l}36 \\
\text { berang }\end{array}$ & & & \\
\hline
\end{tabular}




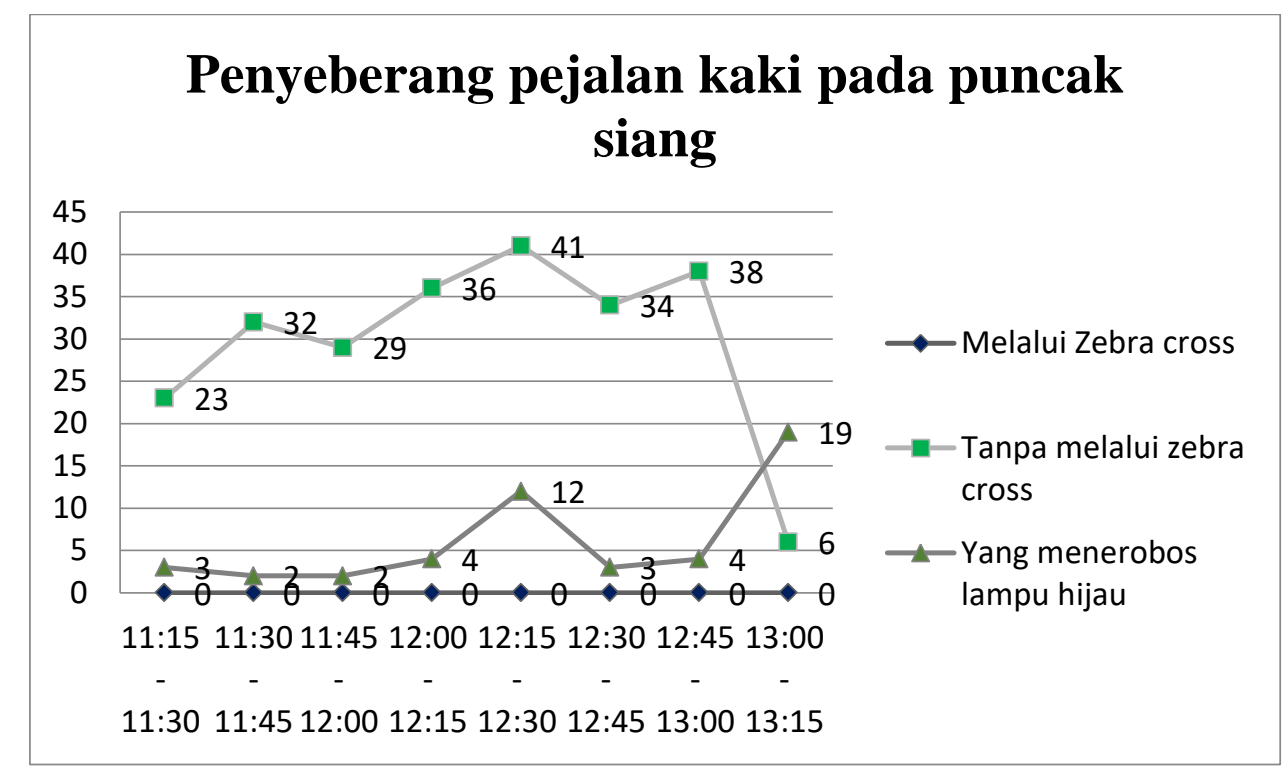

Gambar 5 Perilaku Penyeberang Pejalan Kaki Puncak Pagi

Dari Tabel 5 dan Gambar 5 menunjukkan bahwa pada puncak pagi terdapat kemudian penyeberang yang tidak melalui zebra cross sebanyak 41 penyeberang, penyeberang yang menerobos lampu hijau sebanyak 19 penyeberang kemudian penyeberang pejalan kaki melalui Zebra Cross sebanyak 0 penyeberang. Hasil tersebut menyimpulkan bahwa penyeberang lebih banyak memilih tidak menggunakan Zebra Cross dari pada menyeberang sesuai trafict light atau melalui Zebra Cross. Dan dapat disimpulkan bahwa zebra cross dan trafict light tidak berfungsi efektif.

\section{Persentase Perilaku Penyeberang Pejalan Kaki Puncak Siang}

Pada perhitungan persentase perilaku penyeberang pejalan kaki, jumlah penyeberang masingmasing perilaku dibagi total penyeberang kemudian dikalikan bilangan 100. Dari perhitungan tersebut menghasilkan angka dalam bentuk persen. Berikut hasil perhitungan persentase perilaku penyeberang pejalan kaki :

$>$ Penyeberang Melalui Zebra Cross

$=$

$=\quad \frac{\text { Penyeberang Melalui Zebra Cross } x 100}{\frac{0 \times 100}{282}}$ Total Penyeberang

$=0 \%($ Dibulatkan menjadi $0 \%)$

$>$ Penyeberang Yang Tidak Melalui Zebra Cross

$=\quad$ Penyeberang Yang Tidak Melalui Zebra Cross $x 100$

$=$ Total Penyeberang

$$
\frac{246 \times 100}{282}
$$

$=87,23 \%$ ( Dibulatkan menjadi $87 \%$ )

$>$ Penyeberang Yang Menerobos Lampu Hijau

$=$

$=\frac{\frac{\text { Penyeberang Yang Tidak Melalui Zebra Cross } \times 100}{28 \times 100}}{\text { Total Penyeberang }}$

$=12,77 \%($ Dibulatkan menjadi $13 \%)$ 
Dari hasil perhitungan persentase perilaku dan berdasarkan Gambar 4.5 diketahui persentase penyeberang yang tidak melalui zebra cross lebih tinggi dibanding melalui zebra cross dan yang menerobos lampu hijau. pada siang hari yaitu dengan perbandingan $0 \%$ berbanding $87 \%$ berbanding $13 \%$. Pada puncak pagi penyeberang yang tidak melalui zebra cross lebih banyak dari pada yang tidak mengikuti isyarat trafict light dan melalui zebra cross. Hal ini terjadi karena zebra cross yang ada sudah tidak jelas garisnya.

\section{PENUTUP}

\section{Kesimpulan}

Berdasarkan hasil evaluasi terhadap perilaku penyeberang pejalan kaki di ruas Jalan Gatot Subroto terhadap pengaruh lalu lintas maka yang dapat disimpulkan dari penelitian ini adalah : Pada ruas Jalan Gatot Subroto Selama jam 06:15 - 08:15 penyeberangan tidak efektif. Yang melalui zebra cross : 2, Yang melalui arus jalan : 199, Yang menerobos lampu hijau : 81 dan jam 11:15 - 13:15 penyeberang melalui Zebra Cross penyeberangan tidak efektif. Yang melalui zebra cross : 0 , yang melalui arus jalan :246, yang menerobos lampu hijau : 36 serta jam 16:45 - 17:45 penyeberangan tidak efektif. Yang melalui zebra cross : 0 , yang melalui arus jalan : 81, yang menerobos lampu hijau : 11 .

\section{Saran}

Demi terciptanya keamanan dan kenyamanan antar pengguna lalu lintas khususnya penyeberang pejalan kaki agaknya lebih bersikap dewasa dengan memanfaatkan fasilitas penyeberangan secara maksimal.

Agar pihak terkait mengkondisikan fasilitas zebra cross dimana satu satunya fasilitas penyeberangan pada ruas Jalan Gatot Subroto sebagai fasilitas yang nyaman untuk digunakan dilihat dari fungsi perorangan, bebas dari aktifitas orang

\section{DAFTAR PUSTAKA}

[1] Arifin, Zainul dkk, 2001, Karakteristik dan Analisis Kebutuhan Fasilitas Penyeberangan Jalan di Pusat Kota Makalah Simposium FSTPI Ke-4, Universitas Udayana. Bali.

[2] David O Sears, Jonathan L Freedman, Lawne Peplau, 1985, Psikologi Sosial, Edisi kelima, Jilid 2, Jakarta 13740, Erlangga.

[3] Fika Dian Pratiwi. 2011. (Studi Karakteristik Pergerakan Pejalan Kaki Di Pedestrian Road Stasiun Tugu Yogyakarta), Yogyakarta : Universitas Negeri Yogyakarta.

[4] Mashuri dan Muh.Ikbal.2011. Studi Karakteristik Pejalan Kaki dan Pemilihan Jenis Fasilitas Penyeberangan Pejalan kaki di Kota Palu (Studi Kasus: Jl. Emmi Saelan Depan Mal Tatura Kota Palu). Palu :Staf Pengajar pada KK Transportasi Jurusan Teknik Sipil Universitas Tadulako.

[5] M. Ayu Chandra Kusuma Wardhani. 2010. Studi karakteristik Pejalan Kaki dengan Menggunakan Tiga pendekatan (kasus pada fasilitas pejalan kaki Galabo Surakarta), Surakarta : Universitas Sebelas Maret.

[6] MKJI. 1997. Manual Kapasitas Jalan Indonesia. Jakarta : Bina Marga

[7] UU Nomor 22Tahun 2009 Tentang Lalu Lintas Dan Angkutan Jalan.

[8] Nahdalina, Iwan K Hadihardaja dan Vibry Rozeani.2006. Perhitungan Antrian dan Tundaan Pada Pintu Tol Grogol Menggunakan Metode Gelombang Kejut.Depok : Jurnal Desain dan Konstruksi Fakultas Teknik Universitas Gunadarma.

[9] Rahayuningsih, Tri. 2010. Ketidakpatuhan Pejalan Kaki dalam Menggunakan Jembatan Penyeberangan (Studi Fenomenologis pada Siswa SMA di Jalan Teuku Umar Kota Semarang).Semarang : Universitas Negeri Semarang. 